\title{
Quantifying the contribution of dyes to the mutagenicity of waters under the influence of textile activities
}

\author{
Francine Inforçato Vacchi ${ }^{\mathrm{a}, \mathrm{b}}$, Josiane Aparecida de Souza Vendemiatti ${ }^{\mathrm{b}}$, Bianca Ferreira da Silva ${ }^{\mathrm{c}}$, \\ Maria Valnice Boldrin Zanoni ${ }^{\mathrm{c}}$, Gisela de Aragão Umbuzeiro ${ }^{\mathrm{a}, \mathrm{b}, *}$ \\ a Faculty of Pharmaceutical Sciences, University of São Paulo, USP, São Paulo, SP, Brazil \\ b School of Technology, State University of Campinas, UNICAMP, Limeira, SP, Brazil \\ ${ }^{\mathrm{c}}$ Institute of Chemistry, State University of São Paulo UNESP, Araraquara, SP, Brazil
}

\section{H I G H L I G H T S}

- Six disperse dyes were detected in the tested environmental samples.

- Highest mutagenic potency was found in Piracicaba River downstream.

- Disperse dyes contributed up to $44 \%$ to the observed mutagenicity.

- Combination of chemical analysis and bioassays identified new priority pollutants.

\section{G R A P H I C A L A B S T R A C T}

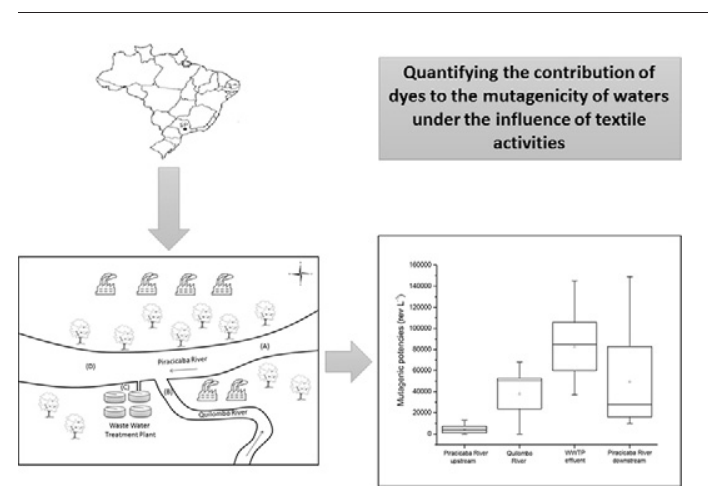

\section{A R T I C L E I N F O}

\section{Article history:}

Received 31 March 2017

Received in revised form 9 May 2017

Accepted 11 May 2017

Available online 26 May 2017

\section{Keywords:}

Dyes

Mutagenicity

Salmonella/microsome assay

Surface water

\begin{abstract}
A B S T R A C T
The combination of chemical analyses and bioassays allows the identification of potentially mutagenic compounds in different types of samples. Dyes can be considered as emergent contaminants and were detected in waters, under the influence of textile activities. The objective of this study was to evaluate the contribution of 9 azo dyes to the mutagenicity of representative environmental samples. Samples were collected along one year in the largest conglomerate of textile industries of Brazil. We analyzed water samples from an important water body, Piracicaba River, upstream and downstream two main discharges, the effluent of a wastewater treatment plant (WWTP) and the tributary Quilombo River, which receives untreated effluent from local industries. Samples were analyzed using a LC-MS/MS and tested for mutagenicity in the Salmonella/microsome microsuspension assay with TA98 and YG1041. Six dyes were detected in the collected samples, Disperse Blue 291, Disperse Blue 373, Disperse Orange 30, Disperse Red 1, Disperse Violet 93, and Disperse Yellow 3. The most sensitive condition for the detection of the mutagenicity was the strain YG1041 with S9. The concentration of dyes and mutagenicity levels varied along time and the dry season represented the worst condition. Disperse Blue 373 and Disperse Violet 93 were the major contributors to the mutagenicity. We conclude that dyes are contributing for the mutagenicity of Piracicaba River water; and both discharges, WWTP effluent and Quilombo River, increase the mutagenicity of Piracicaba River waters in about 10-fold. The combination of chemical analysis and bioassays were key in the identification the main drivers of the water mutagenicity and allows the selection
\end{abstract}

\footnotetext{
* Corresponding author at: School of Technology, State University of Campinas, Limeira, SP, Brazil.

E-mail address: giselau@ft.unicamp.br (G.A. Umbuzeiro).
} 
of priority compounds to be included in monitoring programs as well for the enforcing actions required to protect the water quality for multiple uses.

\section{Introduction}

The combination of chemical analyses and bioassays, such as Effect Directed Analysis (EDA) allows the identification of mutagenic compounds in different types of samples (Brack, 2003). This approach is very interesting for water quality monitoring because the biological tools can be selected based on their ability to detect specific effects and their biological significance. This strategy can identify river basin priority pollutants that are not included in monitoring programs (Brack et al., 2016).

Bioassays, such as the Salmonella/microsome mutagenicity assay, produce an interesting response to a complex mixture evaluation without prior knowledge of the chemical sample composition (Claxton et al., 2004). Because the test can be performed with strains containing different mutation targets and metabolic capacities it allows the identification of several classes of mutagens which would not be identified by targeted chemical analysis (Umbuzeiro et al., 2011; Umbuzeiro et al., 2016). This assay is also considered an important bioanalytical tool and the responses can be linked to specific adverse outcome pathways when the ultimate goal is to protect the quality of the environment at the population level (Altenburger et al., 2015). Several studies have identified water contaminants when applied the combination of chemical analysis and the Salmonella assay (Gallampois et al., 2013; Liu et al., 2015; Muz et al., 2017; Umbuzeiro et al., 2005b).

The most used organic dyes for textiles contain an azo group in their structure (Bafana et al., 2011) and several are genotoxic and mutagenic in mammalian and bacterial tests (Chequer et al., 2009; Josephy et al., 2016; Oliveira et al., 2010; Rajaguru et al., 1999; Tsuboy et al., 2007; Umbuzeiro et al., 2005a). Recently, azo dyes were identified as predominant brominated compounds in house dust and also exhibit mutagenic responses at environmentally relevant concentrations (Peng et al., 2016). Waters containing textile discharges can exhibit genotoxic and mutagenic activity that has been related to the presence of certain dyes and aromatic amines (Oliveira et al., 2007; Umbuzeiro et al., 2005b). However, in the case study of the Cristais River, mutagenic dyes were detected but not quantified and it was not possible to know their contribution in the mutagenicity of the river water (Umbuzeiro et al., 2005b). Considering this, the objective of this study was to identify selected azo dyes in environmental samples following textile discharges and to verify their contribution to the mutagenicity of those samples.

\section{Materials and methods}

\subsection{Study area and sampling}

The biggest pole of textile industries of Brazil is located in Americana city, São Paulo state. Piracicaba River, one of the most important rivers in São Paulo, is the main receiving water body for the liquid effluents generated by the industries. At the same time the river quality is protected by law and must be preserved for multiple uses, including aquatic life protection and human consumption. A wastewater treatment plant (WWTP) is responsible for the collection and treatment of several of the industrial effluents from the textile pole. It uses a biological treatment and the final effluent is discharged into the Piracicaba River. Unfortunately, this type of biological treatment alone is not efficient for the removal of disperse dyes (USEPA, 1990), so it is possible that dyes would remain in the final effluent. Furthermore, the capacity of the WWTP is not sufficient to treat all industrial effluents generated in the area, and several textile factories discharge their effluents, without proper treatment, directly to a tributary of Piracicaba River, called Quilombo. Four sampling campaigns were performed in April, June, August and October of 2013. Samples were collected from the WWTP outflow, Quilombo River and Piracicaba River, upstream and downstream the discharges (Fig. 1). Samples (4 1) were collected using amber glass flasks, transported to the laboratory on ice and immediately processed (APHA, 1999).

\subsection{Liquid-liquid extraction/concentration procedures}

Water samples were liquid-liquid extracted using dichloromethane (DCM) and methanol (2.5:1) as already adopted in other related textile studies (Umbuzeiro et al., 2004). Extracts were rotary evaporated and completely dried with purified nitrogen gas. Extracts were carefully kept frozen and stored in amber vials. For the mutagenicity tests the solvent was exchanged. Adequate volumes of dimethyl sulfoxide (DMSO) were added to the extracts previous diluted in DCM and then DCM was completely evaporated using purified nitrogen gas.

\subsection{HPLC-MS/MS analysis}

Chemical analyses were performed on the same extracts tested for mutagenicity. Analysis were conducted in a High Performance Liquid Chromatography (HPLC) Agilent 1200 system (Waldbronn, Germany) coupled to an AB Sciex 3200 QTRAP hybrid triple quadrupole/linear ion trap mass spectrometer (MS). Extracts were completely dried using purified nitrogen gas and re-suspended in methanol:water (50:50, v/v) containing $0.1 \%$ formic acid. Chromatographic separation was performed in Kinetex PFP analytical column $(150 \mathrm{~mm} \times 4.6 \mathrm{~mm}$; $5 \mu \mathrm{m}$, Phenomenex). As mobile phase water (A) and acetonitrile (B), spiked with $0.1 \%$ formic acid, were used at a flow rate of $1.5 \mathrm{~mL} \mathrm{~min}^{-1}$ and a gradient program for water/acetonitrile: $0-1 \mathrm{~min}$, 5\% B; 1-5.5 min, 5-9\% B; 5.5-6.5 min, 9-25\% B; 6.5-9.5 min, 25-40\% B; $9.5-11.5 \mathrm{~min}, 40-45.5 \% \mathrm{~B}$; $11.5-16.5 \mathrm{~min}, 45.5-60.5 \% \mathrm{~B}$; $16.5-$ $18.5 \mathrm{~min}, 60.5-100 \% \mathrm{~B}, 18.5-23 \mathrm{~min}, 100 \% \mathrm{~B}$ and re-established by $5 \%$ B over $7 \mathrm{~min}$. Column temperature was set to $40{ }^{\circ} \mathrm{C}$, injection volume was $20 \mu \mathrm{L}$, and total run length was $30 \mathrm{~min}$. The 3200 QTRAP was coupled to the chromatographic apparatus via an electrospray ionization (ESI) source operating in positive ion mode with specific parameters: spray voltage, $5500 \mathrm{~V}$; capillary temperature, $650{ }^{\circ} \mathrm{C}$; the nebulizing gas (nitrogen, $45 \mathrm{psi}$ ); the heating gas (nitrogen, $45 \mathrm{psi}$ ) and the curtain gas, 15 psi. Selected reaction monitoring (SRM) mode, with two SRM transitions to eliminate false results were used in the identification of the compounds of interest. Fragmentation parameters were optimized by direct infusion of individual compounds solutions at $0.1 \mathrm{mg} \mathrm{L}^{-1}$ in methanol/water (50:50, v/v) containing $0.1 \%$ formic acid, using a flow of $10 \mu \mathrm{L} \mathrm{min}{ }^{-1}$. In this step, the following parameters were analyzed: Collision Energy (CE), Declustering Potential (DP), Entrance Potential (EP), Cell Entrance Potential (CEP) and Collision Cell Exit (CXP). All properties and parameters of each compound analyzed are summarized in Table 1 and chromatograms are available at Supplementary Material.

The instrumental limit of detection (LOD) and limit of quantification (LOQ) were defined as the minimum amount of the selected compound analyzed by LC-MS/MS considering the signal-to-noise (S/N) ratio of 3 and a $\mathrm{S} / \mathrm{N}$ of 10 , respectively. The compounds were identified by their retention times and their specific SRM transitions. The validation protocol was adapted based on criteria accepted by different institutions (APHA, 1999; USEPA, 1997). The adaptation of different validation guides was 


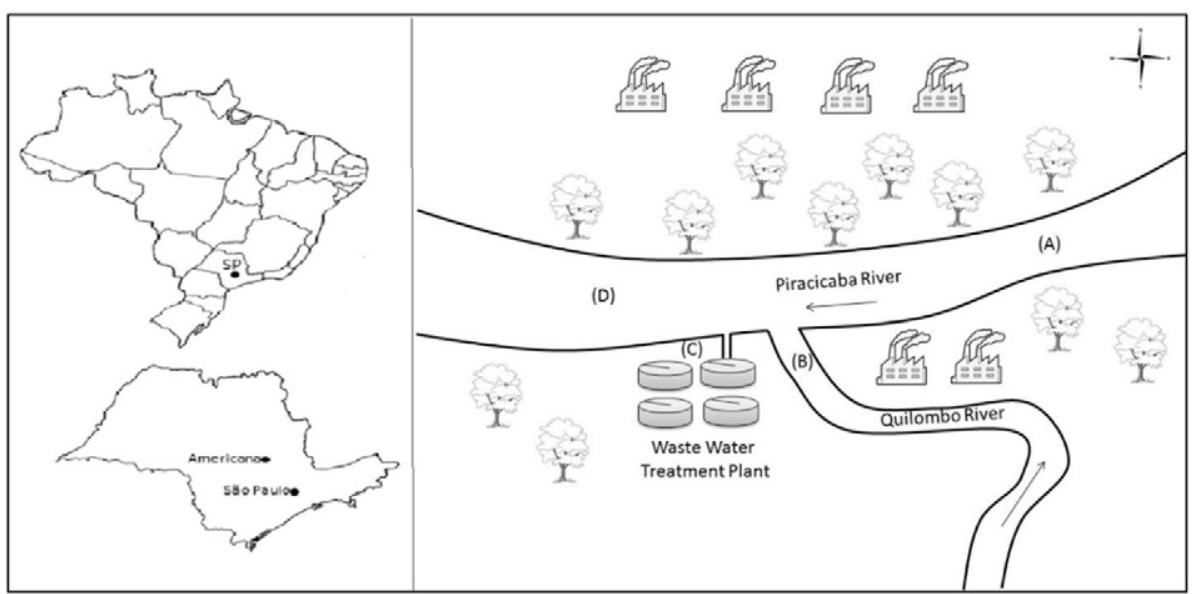

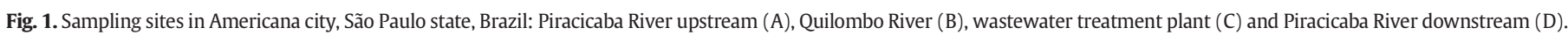

necessary due to the lack of specific guides for analyzing textile dyes in aqueous samples. Analytical curves with five different concentrations were constructed by standard spiking, using triplicate for all points.

The calibration curve was obtained by plotting the area of the chromatographic band of each dye versus the standard analyte concentration (river water spiked to each standard). Standards and $\mathrm{MeOH}$ blanks were injected periodically to ensure that the instrument response was not drifting and that the blanks were free of the analytes.

Recoveries (percent of standard added to sample that was recovered following extraction) were obtained by spiking river water samples before and after extraction in three different concentrations in triplicate. Laboratory blanks and laboratory-fortified blanks were also evaluated to ensure that the analytical method and laboratory equipment were free from outside contamination and to compare recoveries. The study of recovery (Rec) was performed according to the equation $\operatorname{Rec}(\%)=$ $(A / B) \times 100$, where A refers to the area of the spiked sample prior to extraction and $B$ the analyte area in the post-extraction spiked sample.

\subsection{Salmonella/microsome microsuspension assay}

The microsuspension protocol of the Salmonella/microsome assay was used because of its high sensitivity (Kado et al., 1983). Because the strain TA98 has been the most used in monitoring studies and provides the majority of the positive responses for surface water testing (Ohe et al., 2004; Umbuzeiro et al., 2001) we included it in this study. We also selected the strain YG1041 (a derivative of the TA98 that overproduces nitroreductase and $O$-acetyltransferase) (Hagiwara et al., 1993) because it has proven to be very sensitive to the detection of mutagenicity of textile plant effluents containing azo dyes (Freeman, 2013; Oliveira et al., 2006; Umbuzeiro et al., 2005b). If nitroaromatics or aromatic amines are contributing to the mutagenic response of the sample, an increase in the response with YG1041 in relation to its parental strain TA98, is expected. For nitroaromatics the increased response would be obtained without S9 and for aromatic amines, in the presence of S9 (Umbuzeiro et al., 2011).

Table 1

Properties and parameters of each disperse azo dye analyzed by HLPC-MS/MS, using SRM mode.

\begin{tabular}{|c|c|c|c|c|c|c|c|c|c|c|c|c|}
\hline \multirow[b]{2}{*}{ Compounds } & \multirow[b]{2}{*}{$\begin{array}{l}\text { CAS } \\
\text { number }\end{array}$} & \multirow[b]{2}{*}{ Supplier/purity } & \multirow[b]{2}{*}{ Chemical structure } & \multirow[b]{2}{*}{$\begin{array}{l}\text { Retention time } \\
(\mathrm{min})\end{array}$} & \multicolumn{2}{|l|}{ SRM } & \multicolumn{6}{|l|}{ MS/MS } \\
\hline & & & & & $\begin{array}{l}\text { Precursor ion } \\
(\mathrm{m} / \mathrm{z})\end{array}$ & $\begin{array}{l}\text { Fragment ion } \\
(m / z)\end{array}$ & $\begin{array}{l}\text { Dwell time } \\
(\mathrm{ms})\end{array}$ & $\begin{array}{l}\text { DP } \\
(V)\end{array}$ & $\begin{array}{l}\mathrm{EP} \\
(\mathrm{V})\end{array}$ & $\begin{array}{l}\text { CEP } \\
(V)\end{array}$ & $\begin{array}{l}\mathrm{CE} \\
(\mathrm{V})\end{array}$ & $\begin{array}{l}\text { CXP } \\
(V)\end{array}$ \\
\hline \multirow{2}{*}{$\begin{array}{l}\text { Disperse Blue } \\
291\end{array}$} & \multirow[t]{2}{*}{$56548-64-2$} & \multirow{2}{*}{$\begin{array}{l}\text { Shanghai Orgchem Co. } \\
\text { Ltd./95\% }\end{array}$} & & \multirow[t]{2}{*}{19.2} & 511 & 207 & 5 & 56 & 8.5 & 22 & 39 & 4 \\
\hline & & & & & 511 & 192 & 5 & 56 & 8.5 & 22 & 47 & 4 \\
\hline \multirow{2}{*}{$\begin{array}{l}\text { Disperse Blue } \\
373\end{array}$} & \multirow[t]{2}{*}{ 51868-46-3 } & Shanghai Orgchem Co. & & \multirow[t]{2}{*}{19.1} & 533 & 260.4 & 5 & 66 & 5 & 24 & 25 & 4 \\
\hline & & Ltd./95\% & & & 533 & 245.4 & 5 & 66 & 5 & 24 & 33 & 4 \\
\hline \multirow{2}{*}{$\begin{array}{l}\text { Disperse } \\
\text { Orange } 1\end{array}$} & \multirow[t]{2}{*}{ 2581-69-3 } & \multirow[t]{2}{*}{ Sigma Aldrich/96\% } & & \multirow[t]{2}{*}{18.5} & 319 & 169.2 & 5 & 56 & 4 & 24 & 35 & 4 \\
\hline & & & & & 319 & 122.2 & 5 & 56 & 4 & 24 & 29 & 4 \\
\hline \multirow{2}{*}{$\begin{array}{l}\text { Disperse } \\
\text { Orange } 30\end{array}$} & \multirow[t]{2}{*}{$12223-23-3$} & Shanghai Orgchem Co. & & \multirow[t]{2}{*}{17.5} & 450 & 87 & 5 & 46 & 7.5 & 24 & 49 & 4 \\
\hline & & Ltd./95\% & & & 450 & 132 & 5 & 46 & 7.5 & 24 & 33 & 4 \\
\hline \multirow{2}{*}{$\begin{array}{l}\text { Disperse } \\
\text { Orange } 37\end{array}$} & \multirow[t]{2}{*}{ 13301-61-6 } & \multirow[t]{2}{*}{ Sigma Aldrich/96\% } & & \multirow[t]{2}{*}{18.3} & 392 & 351 & 5 & 51 & 5 & 32 & 21 & 6 \\
\hline & & & & & 392 & 133 & 5 & 51 & 5 & 32 & 51 & 4 \\
\hline \multirow{2}{*}{$\begin{array}{l}\text { Disperse Red } \\
\quad 1\end{array}$} & \multirow[t]{2}{*}{$2872-52-8$} & \multirow{2}{*}{ Sigma Aldrich/95\% } & & \multirow[t]{2}{*}{15.1} & 315 & 134 & 5 & 51 & 4 & 24 & 33 & 4 \\
\hline & & & & & 315 & 255 & 5 & 51 & 4 & 24 & 29 & 4 \\
\hline \multirow{2}{*}{$\begin{array}{l}\text { Disperse } \\
\text { Violet } 93\end{array}$} & \multirow[t]{2}{*}{$52697-38-8$} & \multirow{2}{*}{$\begin{array}{l}\text { Shanghai Orgchem Co. } \\
\text { Ltd./95\% }\end{array}$} & & \multirow[t]{2}{*}{18.7} & 481 & 191 & 5 & 56 & 7.5 & 20 & 37 & 4 \\
\hline & & & & & 481 & 206 & 5 & 56 & 7.5 & 20 & 25 & 4 \\
\hline Disperse & $2832-40-8$ & Sigma Aldrich/96\% & & 13.8 & 270.2 & 107.2 & 5 & 41 & 5.5 & 18 & 33 & 4 \\
\hline Yellow 3 & & & & & 270.2 & 108.1 & 5 & 41 & 5.5 & 18 & 39 & 4 \\
\hline Disperse & $6300-37-4$ & Sigma Aldrich/95\% & & 18.1 & 317.1 & 77 & 5 & 51 & 4 & 22 & 47 & 4 \\
\hline Yellow 7 & & & & & 317.1 & 105.1 & 5 & 51 & 4 & 22 & 29 & 4 \\
\hline
\end{tabular}

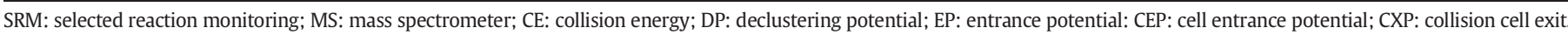


We tested six doses 0.07 to $40 \mathrm{ml}$ equivalent/plate in duplicates. We included negative, solvent and positive controls. Salmonella cultures were centrifuged at $10,000 \mathrm{~g}$ at $4{ }^{\circ} \mathrm{C}$ for $10 \mathrm{~min}$ and re-suspended in $0.015 \mathrm{M}$ sodium phosphate buffer. We employed as exogenous metabolic activation system using 4\% (v/v) Aroclor-1254-induced rat liver S9 fraction (Moltox Inc., Boone, NC) and cofactors. Volumes of $5 \mu \mathrm{l}$ of each extract were incubated at $37^{\circ} \mathrm{C}$ for $90 \mathrm{~min}$ without shaking with $50 \mu \mathrm{l}$ of cell suspension, $50 \mu \mathrm{l}$ of $0.015 \mathrm{M}$ sodium phosphate buffer (or $\mathrm{S} 9 \mathrm{mix}$ ). After addition of the top agar, plates were incubated at $37^{\circ} \mathrm{C}$ for $72 \mathrm{~h}$. Colonies were manually counted under a stereoscope. Visual observation of the background under a stereoscope was used to evaluate toxicity. Positive controls for TA98 were $0.125 \mu \mathrm{g} /$ plate of 4nitroquinoline-oxide (4NQO) (Sigma-Aldrich) without S9 and $0.625 \mu \mathrm{g} /$ plate of 2-aminoanthracene (2AA) (Sigma-Aldrich) with S9, both dissolved in DMSO. For YG1041, $2.5 \mu \mathrm{g} /$ plate of 4-nitro-ophenylenediamine (4NOP) (Sigma-Aldrich) without S9 and $0.03125 \mu \mathrm{g} /$ plate of 2-aminoanthracene (2AA) (Sigma-Aldrich) with S9, dissolved in DMSO. Data were statistically analyzed using an ANOVA followed by linear regression using the Bernstein model (Bernstein et al., 1982). Samples were considered positive when significant ANOVA $(p<0.05)$ and positive dose responses were obtained $(p<0.05)$.

\section{Results \& discussion}

\subsection{Chemical analysis}

The methodology developed in this study was efficient for separation and identification of dyes in environmental matrices, since 6 different dyes were detected and quantified in the samples, Disperse Blue 291, Disperse Blue 373, Disperse Orange 30, Disperse Red 1, Disperse Violet 93, and Disperse Yellow 3, in the range of 0.01 to $6.81 \mu \mathrm{g} \mathrm{L}^{-1}$ (Table 2 ). All the values are in the interval of acceptable recoveries, from 70 to 120\% (APHA, 1999; USEPA, 1997), except for Disperse Blue 373 and Disperse Orange 37, which presented higher recoveries. Because the focus of the work was to apply a method able to analyze all the target dyes at the same time, use the same extracts to test for mutagenicity and verify their contribution we accepted recoveries that were out of the recommended interval for those dyes (Table 2).

Disperse Orange 1, Disperse Orange 37 and Disperse Yellow 7 were not quantified in any sample because their concentrations were lower than their respective detection limits (LOD). The other disperse dyes were detected at least one time during the study (Table 2). Disperse Red 1, Disperse Blue 373 and Disperse Violet 93 dyes were also found in waters under the influence of textile discharges in previous studies (Umbuzeiro et al., 2005b; Zocolo et al., 2015).

The sampling campaign performed during the dry season (Sampling 3 - August/2013), was the most representative of the study. In this campaign six dyes of the nine target dyes were found and in the highest concentrations. These findings highlight the importance of collecting different samples along time to have a reliable study. The fact that the samples from the dry season were the most mutagenic corroborates with the conclusion that the industrial discharges are in fact the main drivers of the mutagenicity of Piracicaba River. When mutagenicity is higher in the wet season it can be related to runoff and not to point sources discharges, which is the case of our study (Valent et al., 1993).

\subsection{Salmonella/microsome microsuspension assay}

The same organic extracts that were chemically analyzed were tested for mutagenicity with Salmonella strains TA98 and YG1041, in the presence and absence of exogenous metabolic activation (S9). TA98 is the most used strain in water mutagenicity studies and responsible for the majority of the positive responses (Ohe et al., 2004; Watanabe et al., 2006; 2002). But in our study all samples presented a negative response with and without S9 for this strain except for one sample from Quilombo River. This sample was positive with TA98 without S9 (Table 3) with a mutagenic potency of 5,500 rev $\mathrm{L}^{-1}$. Umbuzeiro et al. (2001) developed a surface water mutagenicity classification based on the responses of TA98 and TA100, which was also applied by Ohe et al. (2004). This sample is classified as extremely mutagenic $\left(>5,000 \mathrm{rev} \mathrm{L}^{-1}\right)$ revealing a high level of contamination of this water body.

When the YG1041 strain was applied, the mutagenicity was detected in 15 of the 16 samples analyzed, with higher responses with S9 (Table 3 ). This fact suggests that aromatic amines or compounds containing amino groups such as some of our target dyes (Table 2) could be responsible for at least part of the observed mutagenicity. The potencies of the Piracicaba River samples were compared to the ones found in the Cristais River, São Paulo, Brazil that was also impacted with textile discharges (Umbuzeiro et al., 2005b) and tested with YG1041. The potencies observed for Piracicaba River were 10 to 100 times higher than the ones reported for Cristais River. The tributary Quilombo River and the WWTP effluent presented, on average, samples 10 times more potent than Piracicaba River downstream therefore both discharges are contributing to the increase in the mutagenicity observed in Piracicaba River (Fig. 2).

Table 2

Recovery (\%), limits $\left(\mu g \mathrm{~L}^{-1}\right)$, concentrations $\left(\mu \mathrm{L}^{-1}\right)$ and frequency (\%) of azo dyes analyzed in environmental samples.

\begin{tabular}{|c|c|c|c|c|c|c|c|c|c|c|c|c|c|c|c|c|c|c|c|c|}
\hline \multirow[b]{2}{*}{ Dyes } & \multirow[b]{2}{*}{ Recovery (\%) } & \multicolumn{2}{|c|}{ Limits $\left(\mu g \mathrm{~L}^{-1}\right)$} & \multicolumn{4}{|c|}{ Sampling $1\left(\mu \mathrm{g} \mathrm{L}^{-1}\right)$} & \multicolumn{4}{|c|}{ Sampling $2\left(\mu \mathrm{g} \mathrm{L}^{-1}\right)$} & \multicolumn{4}{|c|}{ Sampling $3\left(\mu \mathrm{L}^{-1}\right)$} & \multicolumn{4}{|c|}{$\begin{array}{l}\text { Sampling } 4 \\
\left(\mu \mathrm{g} \mathrm{L}^{-1}\right)\end{array}$} & \multirow[b]{2}{*}{ Frequency (\%) } \\
\hline & & LOD & LOQ & A & B & C & $\mathrm{D}$ & A & B & $\mathrm{C}$ & $\mathrm{D}$ & A & B & C & $\mathrm{D}$ & A & B & C & $\mathrm{D}$ & \\
\hline Disperse Blue 291 & 107 & 0.0022 & 0.0075 & - & - & - & - & - & - & - & - & 0.04 & - & 0.05 & - & - & - & - & - & 12.50 \\
\hline Disperse Blue 373 & 130 & 0.0016 & 0.0054 & - & - & 0.35 & - & - & - & 0.08 & - & - & 1.38 & 0.15 & 3.13 & - & 0.54 & - & 0.28 & 43.75 \\
\hline Disperse Orange 1 & 89 & 0.0022 & 0.0072 & - & - & - & - & - & - & - & - & - & - & - & - & - & - & - & - & 0 \\
\hline Disperse Orange 30 & 70 & 0.0128 & 0.0427 & - & - & - & - & - & - & - & - & - & 0.14 & - & - & - & - & - & - & 6.25 \\
\hline Disperse Orange 37 & 166 & 0.0136 & 0.0228 & - & - & - & - & - & - & - & - & - & - & - & - & - & - & - & - & 0 \\
\hline Disperse Red 1 & 120 & 0.0003 & 0.0010 & 0.52 & - & 0.03 & - & - & - & 0.19 & - & - & 0.09 & 0.08 & 0.11 & - & 0.15 & - & 0.13 & 50.00 \\
\hline Disperse Violet 93 & 91 & 0.0064 & 0.0214 & - & 0.08 & - & - & - & 0.08 & - & - & - & 2.81 & - & 6.81 & - & - & - & - & 25.00 \\
\hline Disperse Yellow 3 & 89 & 0.0020 & 0.0066 & - & - & - & - & - & - & - & - & - & 0.01 & - & 0.03 & - & 0.41 & - & 0.02 & 25.00 \\
\hline Disperse Yellow 7 & 81 & 0.0010 & 0.0032 & - & - & - & - & - & - & - & - & - & - & - & - & - & - & - & - & 0 \\
\hline
\end{tabular}

$-<$ LOD.

LOD: limit of detection.

LOQ: limit of quantification.

A: Piracicaba River upstream.

B: Quilombo River.

C: WWTP effluent.

D: Piracicaba River downstream. 
Table 3

Mutagenic potencies (rev $\mathrm{L}^{-1}$ ) of environmental samples tested with strains TA98 and YG1041, without (-S9) and with (+S9) metabolic activation.

\begin{tabular}{|c|c|c|c|c|c|}
\hline & & \multicolumn{2}{|c|}{ TA98 $\left(\operatorname{rev~L}^{-1}\right)$} & \multicolumn{2}{|c|}{ YG1041 (rev L $\left.{ }^{-1}\right)$} \\
\hline & & $-S 9$ & + S9 & $-S 9$ & + S9 \\
\hline \multirow[t]{4}{*}{ Sampling 1} & A & 0 & 0 & 6,000 & 4,000 \\
\hline & B & 0 & 0 & 0 & 68,000 \\
\hline & C & 0 & 0 & 0 & 145,000 \\
\hline & $\mathrm{D}$ & 0 & 0 & 9,000 & 10,000 \\
\hline \multirow[t]{4}{*}{ Sampling 2} & A & 0 & 0 & 30,000 & 13,000 \\
\hline & B & 0 & 0 & 2,000 & 34,000 \\
\hline & $\mathrm{C}$ & 0 & 0 & 82,000 & 65,000 \\
\hline & $\mathrm{D}$ & 0 & 0 & 41,000 & 28,000 \\
\hline \multirow[t]{4}{*}{ Sampling 3} & A & 0 & 0 & 3,000 & 0 \\
\hline & B & 5,500 & 0 & 5,800 & 50,550 \\
\hline & $\mathrm{C}$ & 0 & 0 & 0 & 85,000 \\
\hline & $\mathrm{D}$ & 0 & 0 & 3,400 & 149,000 \\
\hline \multirow[t]{4}{*}{ Sampling 4} & A & 0 & 0 & 8,000 & 0 \\
\hline & B & 0 & 0 & 0 & 0 \\
\hline & C & 0 & 0 & 0 & 37,000 \\
\hline & $\mathrm{D}$ & 0 & 0 & 21,000 & 11,000 \\
\hline
\end{tabular}

A: Piracicaba River upstream.

B: Quilombo River.

C: WWTP effluent.

D: Piracicaba River downstream.

\subsection{Contribution of target dyes to the observed mutagenicity}

We calculated the individual contributions of the analyzed dyes considering their concentration in each sample and their respective mutagenic potencies in the most mutagenic scenario (YG1041 with S9) (Table 4). Mutagenic potencies of Disperse Blue 291, Disperse Blue 373, Disperse Violet 93 and Disperse Red 1 were previously published for YG1041 and their potencies with S9 are 180; 6,300; 4,600 and

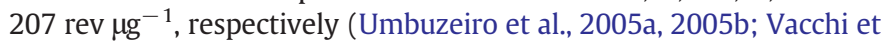
al., 2013). No mutagenicity data was found in the literature for the other two dyes detected in the analyzed samples. Therefore, we tested Disperse Orange 30 and Disperse Yellow 3 with the strain YG1041 and

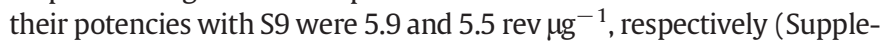
mentary Material).

Disperse Red 1, despite being the most frequent dye detected in the samples, contributed only with 0.004 to $2.7 \%$ of the mutagenicity. But the importance of Disperse Red 1 as an aquatic contaminant should

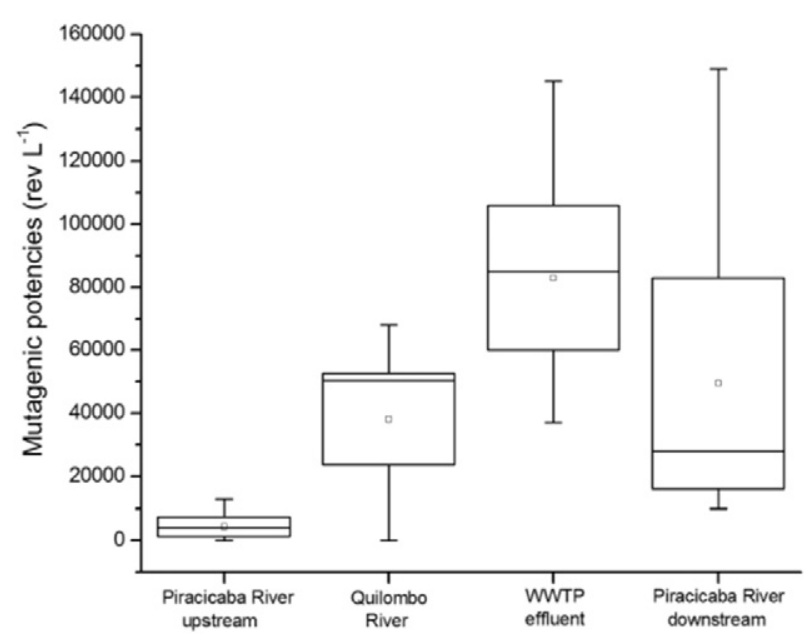

Fig. 2. Mutagenic potencies (rev L ${ }^{-1}$ ) for YG1041, with S9, of Piracicaba River upstream, Quilombo River, WWTP effluent and Piracicaba River downstream. not be overruled. Its concentrations, in both Piracicaba and Quilombo rivers were detected above $60 \mathrm{ng} \mathrm{L}^{-1}$, the Predicted No-Effect Concentration (PNEC) derived by Vacchi et al. (2016b) representing a potential risk to the local biota.

Disperse Blue 373 and Disperse Violet 93 were the major contributors to the mutagenicity in Quilombo River, WWTP effluent and Piracicaba River downstream (up to 17.2 and 25.6\%, respectively) (Table 4) and indeed they have substituted amines in their structure confirming the mutagenic type of response obtained for the analyzed samples. Dyes were found in the WWTP effluents as expected but showed a small contribution to the mutagenicity in comparison to Quilombo River. The high potencies observed for the WWTP samples could be attributed to their breakdown products generates during the treatment process. In fact, Vacchi et al. (2016a) quantified several mutagenic aromatic amines in the same samples but it was not possible to calculate their contribution because the respective mutagenic potencies were not available.

Several authors have used the combination of chemical analyses and bioassays in water and sediment samples to determine which compounds were causing the observed effect such as in Effect-Directed Analysis (EDA) (Brack et al., 2016). These studies usually include a fractionation step of the samples based on their different physicochemical properties, followed by bioassays to reduce the chemical complexity of fractions and facilitate chemical analysis (Brack, 2003). Highly potent nitro-PAHs such as dinitropyrene (DNP) isomers, 3-nitrobenzanthrone (3-NBA) and nitrobenzo[a]pyrenes have been detected in samples of sediment in an industrial area in Germany and, in some fractions of the samples, 1,8-DNP and 3-NBA explained together $>70 \%$ of the mutagenicity (50\% 1,8-DNP and 21\% 3-NBA) (Lübcke-von Varel et al., 2012). In our work, we didn't apply a fractionation step but we could explain $>40 \%$ of the mutagenicity by using strains with different sensitivities combined with the previous knowledge of the possible chemical compounds present in the samples according to the discharge source. This approach has also been successfully applied by Muz et al. (2017) enabling the discovery of new mutagenic compounds in the Danube River in Europe.

It is very important to identify the major compounds that are causing mutagenicity in water bodies, because this provides an opportunity to define new specific water basin priority pollutants that can be included in the monitoring programs. Although there are no cut off values for mutagenicity in surface waters, this type of study provides the basis for enforcement actions to reduce the mutagenic sources minimizing the exposure of humans and biota in rivers with multiple uses, such as Piracicaba River.

\section{Conclusion}

Of the nine selected dyes, six were found in the studied area, Disperse Blue 291, Disperse Blue 373, Disperse Orange 30, Disperse Red 1, Disperse Violet 93, and Disperse Yellow 3, in concentrations from 0.01 to $6.81 \mu \mathrm{g} \mathrm{L}^{-1}$. Samples from the Piracicaba River downstream, Quilombo River, and WWTP effluent presented high levels of mutagenicity up to $149,000 \mathrm{rev} \mathrm{L}^{-1}$. Disperse Blue 373 and Disperse Violet 93 were the major contributors to the mutagenicity of Quilombo River, WWTP effluent and Piracicaba River downstream. Disperse Red 1, although the most frequent dye, detected in $50 \%$ of the samples, accounted for a small contribution to the mutagenicity. The use of Salmonella strains with high sensitivity to the class of the selected dyes (YG1041) was essential to reveal their contribution in these mutagenic environmental water samples. Finally, the combination of chemical analysis and bioassays were key in the identification the main drivers of the water mutagenicity and provides the required tools for the selection of priority compounds to be included in monitoring programs as well for the enforcing actions required to protect the water quality for multiple uses. 
Table 4

Contribution of the dyes to the mutagenicity of samples using strain YG1041 with S9.

\begin{tabular}{|c|c|c|c|c|c|c|c|c|}
\hline \multirow[b]{2}{*}{ Sample site } & \multirow[b]{2}{*}{ Sampling } & \multirow{2}{*}{ 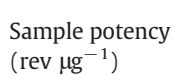 } & \multirow[b]{2}{*}{ Dye } & \multirow{2}{*}{$\begin{array}{l}\text { Dye concentration } \\
\left(\mu \mathrm{g} \mathrm{L}^{-1}\right)\end{array}$} & \multirow{2}{*}{$\begin{array}{l}\text { Dye potency } \\
\left(\mathrm{rev}_{\mu \mathrm{g}^{-1}}\right)\end{array}$} & \multicolumn{2}{|c|}{ Contribution } & \multirow{2}{*}{$\begin{array}{l}\text { Tota } \\
(\%)\end{array}$} \\
\hline & & & & & & $\left(\operatorname{rev~L}{ }^{-1}\right)$ & $(\%)$ & \\
\hline \multirow[t]{4}{*}{ Piracicaba River upstream } & 1 & 4,000 & Disperse Red 1 & 0.52 & $207^{\mathrm{a}}$ & 107.6 & 2.7 & 2.7 \\
\hline & 2 & 13,000 & - & - & 0 & 0 & 0 & \\
\hline & 3 & 0 & Disperse Blue 291 & 0.04 & $180^{\mathrm{b}}$ & 0 & 0 & \\
\hline & 4 & 0 & - & - & 0 & 0 & 0 & \\
\hline \multirow[t]{10}{*}{ Quilombo River } & 1 & 68,000 & Disperse Violet 93 & 0.08 & $4,600^{\mathrm{c}}$ & 368 & 0.5 & 44.4 \\
\hline & 2 & 34,000 & Disperse Violet 93 & 0.08 & $4,600^{\mathrm{c}}$ & 368 & 1.08 & \\
\hline & 3 & 50,550 & Disperse Blue 373 & 1.38 & $6,300^{c}$ & 8,694 & 17.2 & \\
\hline & & & Disperse Orange 30 & 0.14 & 5.9 & 0.83 & 0.001 & \\
\hline & & & Disperse Red 1 & 0.09 & $207^{\mathrm{a}}$ & 18.63 & 0.03 & \\
\hline & & & Disperse Violet 93 & 2.81 & $4,600^{c}$ & 12,926 & 25.6 & \\
\hline & & & Disperse Yellow 3 & 0.01 & 5.5 & 0.06 & 0.0001 & \\
\hline & 4 & 0 & Disperse Blue 373 & 0.54 & $6,300^{c}$ & 0 & 0 & \\
\hline & & & Disperse Red 1 & 0.15 & $207^{\mathrm{a}}$ & 0 & 0 & \\
\hline & & & Disperse Yellow 3 & 0.41 & 5.5 & 0 & 0 & \\
\hline \multirow[t]{8}{*}{ WWTP effluent } & 1 & 145,000 & Disperse Blue 373 & 0.35 & $6,300^{c}$ & 2,205 & 1.52 & 3.5 \\
\hline & & & Disperse Red 1 & 0.03 & $207^{\mathrm{a}}$ & 6.2 & 0.004 & \\
\hline & 2 & 65,000 & Disperse Blue 373 & 0.08 & $6,300^{c}$ & 504 & 0.78 & \\
\hline & & & Disperse Red 1 & 0.19 & $207^{a}$ & 39.3 & 0.06 & \\
\hline & 3 & 85,000 & Disperse Blue 291 & 0.05 & $180^{\mathrm{b}}$ & 9 & 0.01 & \\
\hline & & & Disperse Blue 373 & 0.15 & $6,300^{\mathrm{c}}$ & 945 & 1.11 & \\
\hline & & & Disperse Red 1 & 0.08 & $207^{\mathrm{a}}$ & 16.6 & 0.02 & \\
\hline & 4 & 37,000 & - & - & 0 & 0 & 0 & \\
\hline \multirow[t]{9}{*}{ Piracicaba River downstream } & 1 & 10,000 & - & - & 0 & 0 & 0 & 34.5 \\
\hline & 2 & 28,000 & - & - & 0 & 0 & 0 & \\
\hline & 3 & 149,000 & Disperse Blue 373 & 3.13 & $6,300^{c}$ & 19,719 & 13 & \\
\hline & & & Disperse Red 1 & 0.11 & $207^{\mathrm{a}}$ & 22.77 & 0.01 & \\
\hline & & & Disperse Violet 93 & 6.81 & $4,600^{\mathrm{c}}$ & 31,326 & 21 & \\
\hline & & & Disperse Yellow 3 & 0.03 & 5.5 & 0.17 & 0.0001 & \\
\hline & 4 & 11,000 & Disperse Blue 373 & 0.28 & $6,300^{c}$ & 1.8 & 0.016 & \\
\hline & & & Disperse Red 1 & 0.13 & $207^{a}$ & 47.6 & 0.43 & \\
\hline & & & Disperse Yellow 3 & 0.02 & 5.5 & 0.11 & 0.001 & \\
\hline
\end{tabular}

\footnotetext{
$-<$ LOQ.

a Vacchi et al. (2013).

b Umbuzeiro et al. (2005b).

c Umbuzeiro et al. (2005a).
}

\section{Acknowledgment}

The authors thank FAPESP (2008/10449-7 and 2012/13344-7) and CAPES (PNPD fellowship) for financial support; Department of Water \& Sewage of Americana City/SP, Brazil, especially to Msc. Guilherme Thiago Maziviero; and Dr. Errol Zeiger for his valuable suggestions.

\section{Appendix A. Supplementary data}

Supplementary data to this article can be found online at http://dx. doi.org/10.1016/j.scitotenv.2017.05.103.

\section{References}

Altenburger, R., Ait-Aissa, S., Antczak, P., Backhaus, T., Barceló, D., Seiler, T.-B., Brion, F. Busch, W., Chipman, K., de Alda, M.L., de Aragão Umbuzeiro, G., Escher, B.I., Falciani, F., Faust, M., Focks, A., Hilscherova, K., Hollender, J., Hollert, H., Jäger, F., Jahnke, A. Kortenkamp, A., Krauss, M., Lemkine, G.F., Munthe, J., Neumann, S., Schymanski, E.L., Scrimshaw, M., Segner, H., Slobodnik, J., Smedes, F., Kughathas, S., Teodorovic, I., Tindall, A.J., Tollefsen, K.E., Walz, K.-H., Williams, T.D., Van den Brink, P.J., van Gils, J., Vrana, B., Zhang, X., Brack, W., 2015. Future water quality monitoring adapting tools to deal with mixtures of pollutants in water resource management. Sci. Total Environ. 512-513:540-551. http://dx.doi.org/10.1016/j.scitotenv.2014.12. 057.

APHA, 1999. Standard methods for the examination of water and wastewater. Am. Public Heal. Assoc. Am. Water Work. Assoc. Water Environ. Fed. 541.

Bafana, A., Devi, S., Chakrabarti, T., 2011. Azo dyes: past, present and the future. Environ. Rev. 370:350-370. http://dx.doi.org/10.1139/A11-018.

Bernstein, L., Kaldor, J., McCann, J., Pike, M.C., 1982. An empirical approach to the statistical analysis of mutagenesis data from the Salmonella test. Mutat. Res. 97, 267-281.

Brack, W., 2003. Effect-directed analysis: a promising tool for the identification of organic toxicants in complex mixtures? Anal. Bioanal. Chem. 377:397-407. http://dx.doi.org/ 10.1007/s00216-003-2139-z.

Brack, W., Ait-Aissa, S., Burgess, R.M., Busch, W., Creusot, N., Di Paolo, C., Escher, B.I., Mark Hewitt, L., Hilscherova, K., Hollender, J., Hollert, H., Jonker, W., Kool, J., Lamoree, M., Muschket, M., Neumann, S., Rostkowski, P., Ruttkies, C., Schollee, J., Schymanski,
E.L., Schulze, T., Seiler, T., Tindall, A.J., De Aragão Umbuzeiro, G., Vrana, B., Krauss, M., 2016. Effect-directed analysis supporting monitoring of aquatic environments an in-depth overview. Sci. Total Environ. 544:1073-1118. http://dx.doi.org/10. 1016/j.scitotenv.2015.11.102.

Chequer, F.M.D., Angeli, J.P.F., Ferraz, E.R.A., Tsuboy, M.S., Marcarini, J.C., Mantovani, M.S. de Oliveira, D.P., 2009. The azo dyes disperse red 1 and disperse orange 1 increase the micronuclei frequencies in human lymphocytes and in HepG2 cells. Mutat. Res. 676: 83-86. http://dx.doi.org/10.1016/j.mrgentox.2009.04.004.

Claxton, L.D., Matthews, P.P., Warren, S.H., 2004. The genotoxicity of ambient outdoor air a review: Salmonella mutagenicity. Mutat. Res. 567:347-399. http://dx.doi.org/10. 1016/j.mrrev.2004.08.002.

Freeman, H., 2013. Aromatic amines: use in azo dye chemistry. Front. Biosci. 18:145-164. http://dx.doi.org/10.2741/4093.

Gallampois, C.M.J., Schymanski, E.L., Bataineh, M., Buchinger, S., Krauss, M., Reifferscheid, G., Brack, W., 2013. Integrated biological-chemical approach for the isolation and selection of polyaromatic mutagens in surface waters. Anal. Bioanal. Chem. 405: 9101-9112. http://dx.doi.org/10.1007/s00216-013-7349-4.

Hagiwara, Y., Watanabe, M., Oda, Y., Sofuni, T., Nohmi, T., 1993. Specificity and sensitivity of Salmonella typhimurium YG1041 and YG1042 strains possessing elevated levels of both nitroreductase and acetyltransferase activity. Mutat. Res. 291, 171-180.

Josephy, P.D., Zahid, M., Dhanoa, J., de Souza, G.B.D., Groom, H., Lambie, M., 2016. Potent mutagenicity in the Ames test of 2-cyano-4-nitroaniline and 2,6-dicyano-4nitroaniline, components of disperse dyes. Environ. Mol. Mutagen. 57:10-16. http:// dx.doi.org/10.1002/em.21983.

Kado, N.Y., Langley, D., Eisenstadt, E., 1983. A simple modification of the Salmonella liquidincubation assay. Increased sensitivity for detecting mutagens in human urine. Mutat. Res. 121, 25-32.

Liu, L., Chen, L., Floehr, T., Xiao, H., Bluhm, K., Hollert, H., Wu, L., 2015. Assessment of the mutagenicity of sediments from Yangtze River estuary using Salmonella typhimurium/ microsome assay. PLoS One 10, e0143522. http://dx.doi.org/10.1371/journal.pone. 0143522.

Lübcke-von Varel, U., Bataineh, M., Lohrmann, S., Löffler, I., Schulze, T., Flückiger-Isler, S., Neca, J., Machala, M., Brack, W., 2012. Identification and quantitative confirmation of dinitropyrenes and 3-nitrobenzanthrone as major mutagens in contaminated sediments. Environ. Int. 44:31-39. http://dx.doi.org/10.1016/j.envint.2012.01.010.

Muz, M., Krauss, M., Kutsarova, S., Schulze, T., Brack, W., 2017. Mutagenicity in surface waters: synergistic effects of carboline alkaloids and aromatic amines. Environ. Sci. Technol. 51:1830-1839. http://dx.doi.org/10.1021/acs.est.6b05468.

Ohe, T., Watanabe, T., Wakabayashi, K., 2004. Mutagens in surface waters: a review. Mutat. Res. 567:109-149. http://dx.doi.org/10.1016/j.mrrev.2004.08.003. 
Oliveira, D.P., Carneiro, P.A., Rech, C.M., Zanoni, M.V.B., Claxton, L.D., Umbuzeiro, G.A 2006. Mutagenic compounds generated from the chlorination of disperse azo-dyes and their presence in drinking water. Environ. Sci. Technol. 40:6682-6689. http:// dx.doi.org/10.1021/es061020p.

Oliveira, D.P., Carneiro, P.A., Sakagami, M.K., Zanoni, M.V.B., Umbuzeiro, G.A., 2007. Chemical characterization of a dye processing plant effluent - identification of the mutagenic components. Mutat. Res. 626:135-142. http://dx.doi.org/10.1016/j.mrgentox. 2006.09.008.

Oliveira, G.A.R., Ferraz, E.R.A., Chequer, F.M.D., Grando, M.D., Angeli, J.P.F., Tsuboy, M.S., Marcarini, J.C., Mantovani, M.S., Osugi, M.E., Lizier, T.M., Zanoni, M.V.B., Oliveira, D.P., 2010. Chlorination treatment of aqueous samples reduces, but does not eliminate, the mutagenic effect of the azo dyes disperse red 1, disperse red 13 and disperse Orange 1. Mutat. Res. 703:200-208. http://dx.doi.org/10.1016/j.mrgentox.2010.09. 001.

Peng H., Saunders, D.M.V., Sun, J., Jones, P.D., Wong C.K.C., Liu, H., Giesy, J.P., 2016. Mutagenic azo dyes, rather than flame retardants, are the predominant brominated compounds in house dust. Environ. Sci. Technol. 50:12669-12677. http://dx.doi.org/10. 1021/acs.est.6b03954.

Rajaguru, P., Fairbairn, L., Ashby, J., 1999. Genotoxicity studies on the azo dye direct red 2 using the in vivo mouse bone marrow micronucleus test. Mutat. Res. 444, 175-180.

Tsuboy, M.S., Angeli, J.P.F., Mantovani, M.S., Knasmüller, S., Umbuzeiro, G.A., Ribeiro, L.R. 2007. Genotoxic, mutagenic and cytotoxic effects of the commercial dye CI disperse Blue 291 in the human hepatic cell line HepG2. Toxicol. in Vitro 21, 1650-1655.

Umbuzeiro, G.A., Roubicek, D.A., Sanchez, P.S., Sato, M.I., 2001. The Salmonella mutagenicity assay in a surface water quality monitoring program based on a 20 -year survey. Mutat. Res. 491, 119-126.

Umbuzeiro, G., Roubicek, D.A., Rech, C.M., Sato, M.I.Z., Claxton, L.D., 2004. Investigating the sources of the mutagenic activity found in a river using the Salmonella assay and different water extraction procedures. Chemosphere 54:1589-1597. http://dx.doi.org/ 10.1016/j.chemosphere.2003.09.009.

Umbuzeiro, G.A., Freeman, H., Warren, S.H., Kummrow, F., Claxton, L.D., 2005a. Mutagenicity evaluation of the commercial product CI disperse Blue 291 using different protocols of the Salmonella assay. Food Chem. Toxicol. 43, 49-56.

Umbuzeiro, G.A., Freeman, H.S., Warren, S.H., de Oliveira, D.P., Terao, Y., Watanabe, T., Claxton, L.D., 2005b. The contribution of azo dyes to the mutagenic activity of the Cristais River. Chemosphere 60:55-64. http://dx.doi.org/10.1016/j.chemosphere. 2004.11.100.

Umbuzeiro, G., Machala, M., Weiss, J., 2011. Diagnostic tools for effect-directed analysis of mutagens, AhR agonists, and endocrine disruptors. In: Brack, W. (Ed.), Effect-Directed Analysis of Complex Environmental Contamination, The Handbook of Environmental Chemistry. Springer, Berlin Heidelberg, Berlin, Heidelberg http://dx.doi.org/10.1007/ 978-3-642-18384-3.
Umbuzeiro, G.D.A., Heringa, M., Zeiger, E., 2016. In vitro genotoxicity testing: significance and use in environmental monitoring. Advances in Biochemical Engineering/Biotechnology http://dx.doi.org/10.1007/10_2015_5018.

USEPA, 1990. Aerobic and anaerobic treatment of C.I. Disperse Blue 79., United States Environmental Protection Agency. United States Environmental Protection Agency, Cincinnati, USA.

USEPA, 1997. Manual for the Certification of Laboratories Analyzing Drinking Water: criteria and Procedures, 45268. EPA 815 B-97-001. United States Environmental Protection Agency, Cincinnati, USA.

Vacchi, F.I., Albuquerque, A.F., Vendemiatti, J.A., Morales, D.A., Ormond, A.B., Freeman, H.S., Zocolo, G.J., Zanoni, M.V.B., Umbuzeiro, G., 2013. Chlorine disinfection of dye wastewater: implications for a commercial azo dye mixture. Sci. Total Environ. 442: 302-309. http://dx.doi.org/10.1016/j.scitotenv.2012.10.019.

Vacchi, F.I., Vendemiatti, J.A.S., Brosselin, V., Ferreira da Silva, B.B., Zanoni, M.V., DeMeo M., Bony, S., Devaux, A., Umbuzeiro, G.A., 2016a. Combining different assays and chemical analysis to characterize the genotoxicity of waters impacted by textile discharges. Environ. Mol. Mutagen. 57:559-571. http://dx.doi.org/10.1002/em.22034.

Vacchi, F.I., Von der Ohe, P.C., de Albuquerque, A.F., Vendemiatti, J.A. de S., Azevedo, C.C.J. Honório, J.G., da Silva, B.F., Zanoni, M.V.B., Henry, T.B., Nogueira, A.J., Umbuzeiro, G. de A., 2016b. Occurrence and risk assessment of an azo dye - the case of disperse red 1. Chemosphere 156:95-100. http://dx.doi.org/10.1016/j.chemosphere.2016.04.121.

Valent, G.U., Sato, M.I.Z., Cristina, M. Coelho, L.S., Coimbrão, C.A., Sanchez, P.S., Martins, M.T., Bonatelli, R., 1993. Monitoring São Paulo state rivers in brazil for mutagenic activity using the Ames test. Environ. Toxicol. Water Qual. 8:371-381. http://dx.doi.org/ 10.1002/tox.2530080403.

Watanabe, T., Shiozawa, T., Takahashi, Y., Takahashi, T., Terao, Y., Nukaya, H., Takamura, T. Sawanishi, H., Ohe, T., Hirayama, T., Wakabayashi, K., 2002. Mutagenicity of two 2phenylbenzotriazole derivatives, 2-[2-(acetylamino)-4-(diethylamino)-5methoxyphenyl]-5-amino-7-bromo-4-chloro-2H-benzotriazole and 2-[2(acetylamino)-4-(diallylamino)-5-methoxyphenyl]-5-amino-7-bromo-4-chloro-2Hbenzotriazole and t. Mutagenesis 17:293-299. http://dx.doi.org/10.1093/mutage/17. 4.293.

Watanabe, T., Ohba, H., Asanoma, M., Hasei, T., Takamura, T., Terao, Y., Shiozawa, T. Hirayama, T., Wakabayashi, K., Nukaya, H., 2006. Isolation and identification of nonchlorinated phenylbenzotriazole (non-CIPBTA)-type mutagens in the Ho River in Shizuoka Prefecture, Japan. Mutat. Res. Genet. Toxicol. Environ. Mutagen. 609:137-145. http://dx.doi.org/10.1016/j.mrgentox.2006.06.033.

Zocolo, G.J., Pilon dos Santos, G., Vendemiatti, J., Vacchi, F.I., Umbuzeiro, G. de A., Zanoni M.V.B., 2015. Using SPE-LC-ESI-MS/MS analysis to assess disperse dyes in environmental water samples. J. Chromatogr. Sci. 53:1257-1264. http://dx.doi.org/10.1093/ chromsci/bmu221. 